\title{
RPL13A wt Allele
}

National Cancer Institute

\section{Source}

National Cancer Institute. RPL13A wt Allele. NCI Thesaurus. Code C104762.

Human RPL13A wild-type allele is located in the vicinity of 19q13.3 and is approximately 8 $\mathrm{kb}$ in length. This allele, which encodes $60 \mathrm{~S}$ ribosomal protein $\mathrm{L} 13 \mathrm{a}$, is involved in translation as a structural protein of the 605 ribosome subunit. 